\title{
Plant Provocations: Botanical Indigeneity and (De)colonial Imaginations
}

\author{
Narendran Kumarakulasingam* \\ Mvuselelo Ngcoya**
}

\begin{abstract}
This paper examines the possibilities and limitations of an emergent global discourse of indigeneity to offer an oppositional praxis in the face of the depredations of settler colonialism in post-apartheid South Africa. Self-conscious articulations of indigeneity, we argue, reveal the fraught relationship between increasingly hegemonic and narrow understandings of the indigenous and the carceral logic of apartheid. We examine this by focusing on the meanings and attachments forged through indigenous plants in two realms: the world of indigenous gardening practised by white suburban dwellers and that of subsistence farming undertaken by rural black women. This juxtaposition reveals that in contrast to the pervasive resurrection of colonial time that defines metropolitan indigenous gardening, the social relations of a subsistence cultivator challenge the confines of colonial temporality, revealing a creative mode of dissent structured around dreams, ancestral knowledge, and the commons. Our exploration of struggles around botanical indigeneity suggests that anticolonial modes of indigeneity do not necessarily inhere in recognisable forms and that studies of the indigenous need to proceed beyond those that bear familial resemblance to emergent global understandings.
\end{abstract}

Keywords: Indigeneity; Colonial; South Africa; Gardening; Subsistence; Race; Temporality.

\section{Introduction}

'Imbuya grows easily and is a good source of nutrition,' our host, Ms Fakazile Mthethwa (affectionately known as Gogo Qho), told us, pointing to a tall slender plant growing right next to some maize and dagga. Earlier that morning our visiting party, consisting of six officials from the Department of Agriculture and Rural Development and the two of us, had stood on the unpaved road that wound through her village of KwaBhoboza, connecting interior villages of the Mpukunyoni Traditional Authority to the national N2 highway. Standing on the edge of the slope that Gogo Qho called her home garden, we had been

* University of KwaZulu-Natal, Durban-KZN; South Africa ; narenkum@gmail.com.

** University of KwaZulu-Natal, Durban-KZN; South Africa; ngcoyam2@ukzn.ac.za. 
unable to distinguish imifino from non-indigenous plants. Instead of neatly tended rows of vegetables, we were presented with what looked to be an overgrown patch of hillside; a tangle of trees, shrubs and climbers grew haphazardly amidst what looked to be strewn about bones, tins, and cut-out plastic bottles. But now, as our guide showed us leaf-by-leaf, plant-by-plant all the imifino she was nurturing, we began to see amadumbe, izintanga, imbuya and the two dozen kinds of imifino growing amidst the more than 70 kinds of plants surrounding us.

Imifino is the collective noun isiZulu speakers in KwaZulu-Natal use when referring to auto-propagating leafy green vegetables that have a penchant for thriving in marginal soil. As interest in indigenous plants has grown, these vegetables - long an unheralded staple of the rural poor (Vorster et al 2007) - are now at the centre of state and scientific attention. Plans are afoot to codify, patent, and popularise 'indigenous knowledges' for a variety of ends: the enhancement of national competitiveness; revalorisation of indigeneity; pursuit of food security; and of course the stimulation of profit-making (Ntuli et al. 2012; Nestlé 2015).

Our presence on that modest hillside too was occasioned by this shift. We had gathered there after hearing about Gogo Qho's unique skill and passion for growing a plethora of rare indigenous plants through agro-ecological methods in her fierce quest to eat only what she grows and grow what she eats. 'Can indigenous plants and knowledges', what we call botanical indigeneity, 'enable food autonomy to take root in the arid soil of this former Bantustan?' we wondered.

Over time, our conversations with Gogo Qho and other subsistence cultivators in the Mtubatuba area, located in north-eastern KwaZulu-Natal, have revealed that imifino are variously considered wild, a tolerated weed among crops, and a source of sustenance during times of hardship. Recollections over shared meals and walks situated imifino within realms of ancestral knowledge, culinary and cultivation practices, as well as familial memories, provoking us to consider nourishment in more than biological/material terms. Strikingly absent from our conversations were any proprietary claims revolving around autochthony or even nativity, in sharp contrast to an emerging global discourse on indigeneity (Geschiere and Nyamnjoh 2000) or South African anxieties around invasive plants (Comaroff and Comaroff 2001). In the wake of the close association between transnational indigenous activism and the United Nations culminating in the United Nations Declaration on Indigenous Peoples (Niezen 2003; Anaya 2004; Merlan 2009), contemporary understandings of indigeneity turn on the concept of historical occupancy of a place (see Lee 2006: 458-459; Ives 2014: 700), or what Mary Louise Pratt calls (2007: 398) 'prior-ity'. As such, the legitimacy and even legibility of 'indigenous' claims vis-à-vis states for restitution, rights, and equality increasingly depend upon the ability of indigenous claimants to demonstrate their connection to, or occupations of land, prior to the colonial encounter. However, the black, mostly women subsistence cultivators who attempted to impart a basic literacy of imifino to us neither spoke in the idiom of the historical nor attempted to affix themselves or the plants we spoke of to land or territory. 
Subsistence cultivators, however, are not alone in cultivating indigenous flora. About three hours south, in the city of Durban (and throughout South Africa) something called 'indigenous gardening' has gained popularity since the end of formal apartheid. As we elaborate later, 'indigenous gardening' is a name reserved for a specialised field of activity, a metropolitan affair practised by conservationists, botanists, real estate developers, horticulturalists, architects, and enjoyed by mostly white upper class homeowners for a variety of purposes, especially those associated with conservation. It is sanctioned by science and other kinds of credentialed expertise, and geared towards enabling overwhelmingly white metropolitan home owners to pursue ecologically friendly ways of aesthetising their properties, rather than towards matters of subsistence undertaken by those deemed the black rural poor. From the vantage point of our conversations with subsistence cultivators like Gogo Qho, we wonder, 'Why do overwhelmingly white metropolitan homeowners specifically want indigenous plants to adorn their properties? What kind of desire for indigeneity is being pursued here? What is indigenous about indigenous gardening other than plants?'

How do we make sense of this divergence between global and local understandings of the indigenous, as well as between two local views? Do we declare them to be separate realms or do we pursue connections between the global and the local across 'disjuncture and difference' to use Arjun Appadurai's (1990) felicitous phrase? Following Anna Tsing (2005), we conceive of this divergence as an instance of the friction through which universals are generated and reformulated. Universals, Tsing (2005: 1) reminds us, are not 'self-fulfilling abstract truth[s]' but instead forged through misunderstandings, divergent meanings and tension. Thus, while politics, like capitalism and science, 'spreads through aspirations to fulfill universal dreams and schemes', such aspirations can nevertheless 'only be charged and enacted in the sticky materiality of practical encounters.' In line with this, we explore the production of indigeneity through our ethnographic encounters with human-plant relations in South Africa. Crucially, by focusing on the 'awkwardness' or gap between understandings of indigeneity and imifino, we illustrate the inability of historically oriented global discourses of indigeneity to successfully challenge the colonial in contemporary South Africa. Our explorations highlight how neither imifino cultivation nor indigenous gardening seamlessly fits in with conceptions of indigeneity advanced by international actors. If botanical indigeneity emerges for us in the failure of 'prior-ity' to take root in South Africa, this failure in turn makes visible contemporary struggles to resurrect as well as displace colonial/apartheid temporality. We begin not with plants, but with a walk - a very long one at that.

\section{Failing to fix: the frictions of firstness}

In March 2015, a group of 18 Khoisan people walked a distance of $1300 \mathrm{~km}$, from the Kalahari to Cape Town, to deliver a petition to the government. Dressed in skins and relying heavily on foraged wild herbs and plants (especially the leafless spiny succulent hoodia, which is believed to be an appetite suppressant) like their ancestors, the walkers were protesting the government's attempt to lump them together with people of Mbo and Nguni 
descent (News24 2016). Instead, the walkers wanted unequivocal official recognition as first peoples. However, when they finally reached Cape Town after eight days, there was no one from the government to receive them. Even more remarkably, there were fewer than 50 people to cheer the walkers as they concluded this punishing walk (Riebesel 2005).

While there are a number of noteworthy aspects to this story, it came to our attention on account of the government's response, or rather non-response. As recipients of a national research grant associated with the post-apartheid government's attempt to revalorise indigeneity as a means of undoing the manifold violence of apartheid, we wondered about the lack of resonance to this expression of indigeneity by the Khoisan. Moreover, our puzzlement was heightened by the fact that South Africa, unlike other African states, has been supportive of indigenous rights. For instance, it was one of only three African countries to approve the U.N. Declaration on the Rights of Indigenous Peoples in 2006 (Hodgson 2009, 20). Furthermore, the national motto is written in the Khoisan language of the /Xam people (!ke e: /xarra //ke, meaning diverse people unite). What might this failure to resonate illustrate?

In asking to be singled out from those of Mbo and Nguni descent, the walkers were both reclaiming a sense of indigenous identity and articulating a sense of indigenousness drawn from an increasingly powerful global discourse (Li 2000). Thanks to the sustained activism of transnational indigenous movements (Nietschmann 1994), indigeneity has emerged as an important global legal and normative category that promises to provide restitution, justice, and equality to indigenous groups marginalised by (post)colonial states (Niezen 2003; Anaya 2004; Moreton-Robinson 2007). However, in the face of diverse indigenous movements and aspirations (de la Cadena and Starn 2007), international actors have attempted to institutionalise a schematic understanding that relies on a combination of: prior occupancy of territory (firstness); self-identification; marginalisation; and commitment to preserving identity and custom. Central to this schematisation, Pratt argues, is the notion of prior-ity, the claim on the part of the colonised or the indigenous to territory prior to the arrival of the settler. Congealed within this notion of priority is both a special connection to a place (Ives 2014), as well as the claim of having been in that place before the arrival of the settler (Pratt 2007).

In emphasising their special connection to place and time (prior to the arrival of the Mbo, Nguni, and the European settlers), the Khoisan were attempting to claim for themselves the role of first peoples in what is today South Africa. However, if they were attempting to articulate a global discourse of firstness, such an articulation could not proceed smoothly because of at least two reasons: first, the clear temporal line that the Khoisan were forced to draw was not between them and white settlers but rather with African co-sufferers, who had also been marginalised and indigenised by the process of settler colonialism. While there is an ongoing history to (re)claim a distinctive Khoisan identity in the last two decades (Schweitzer 2015), a long history of coexistence, intermarriage and incorporation between various Khoisan and Bantu peoples, and between Khoisan and Europeans have made this extremely difficult (Lee 2003, 2006: 461-468). Approximately 60 per cent of the South African population of mixed race are of Khoisan descent (Barbieri et 
al. 2014) - a testament to Khoisan/European admixture, while the pervasive click sounds found in isiZulu, isiXhosa, isiSwazi are thought to be the result of Khoisan maternal ancestors passing on (Khoisan) linguistic inflections to their progeny (Lee 2006). As such, firstness could not materialise with the same normative effect as in other settler states as the addressee of the Khoisan claim represented not an alien settler state but indigenous co-sufferers.

Second, the nature of the line that the Khoisan were seeking to draw is analogous to the logic of apartheid, which defined and categorised people into distinctive groups based on occupancy of, or connection to place (Dubow 1989; Ashforth 1990: 22-46). As Mahmood Mamdani (2012) argues, the settler fabrication of the native was defined through emplacement. To be native was to be defined by place and by place alone. In South Africa, this resulted in the creation of absurd categories such as the 'foreign native' (Neocosmos 2006) and laws such as the Group Areas Act of $1950^{1}$ and the Native Act of $1952 .^{2}$ Thus in seeking to articulate firstness, the Khoisan were emplacing both themselves and other African peoples into distinct territories, resurrecting the logic of spatiality that underlay apartheid.

Resultantly, while indigeneity may work well in other parts of the world as an 'oppositional, place-based existence' (Alfred and Corntassel 2005: 597), in contemporary South Africa, the legacies of colonialism and apartheid make attempts to fix indigeneity through firstness quite difficult, if not impossible. In the wake of this failure, we turn to another attempt - one using indigenous plants - to assert indigenousness.

\section{Absurd fixings: indigenous gardening}

We stumbled upon indigenous gardening by accident when we saw colourful posters in the posh Glenwood area of Durban advertising the annual Indigenous Plant Fair to be held at Munies Sports Field, below the Durban Botanic Gardens. While we have attended similar events in the last three years, that first visit was memorable. There were dozens of exhibitors, municipal workers, botanists, gardeners, landscapers, conservationists, and enthusiasts poring over plants, lists of local nurseries, as well as books and pamphlets identifying 'indigenous' plants. What struck us immediately was the absence of black people at the fair; it was a distinctly white affair, except for the black ushers and workers, conspicuous in their orange pinafores, helping push customers' shopping carts.

Walking around viewing the plants arranged by type (woody shrubs or herbaceous plants), function (ground covers, shade and hedge plants) and lifespan (such as perennials, annuals or ephemerals), we noted the absence of edible indigenous vegetables or of any information on the medicinal or culinary properties of plants, something we were accustomed to because of our work with Ms Mthethwa. Indeed, the cultivation of indigenous plants largely for aesthetic purposes would be considered strange among our Zulu interlocutors. Perusing the plants produced a sense of further unease whose sources we had trouble identifying - until our eyes alighted on a neatly arranged row of plants, each wearing a white bar-coded label: 'Zantedeschia aethiopica, Green-leaf arum, $9 \mathrm{~cm}$ bulb, 
damp soil. Price: R33.' The plant looked familiar but the strange name gave us pause. It took a little while before we realised that what we were looking at was intebe, a very common plant that can be found growing freely and is often used to treat insect bites. In this invocation of intebe as Zantedeschia aethiopica, what is excised is the convention of naming in isiZulu, which is predicated upon a sociality with plants. Thus the name usondelangange (come closer so I can embrace you) for the thorny bush that snags passers-by; isicishamlilo (fire extinguisher) for a medicinal plant used to reduce inflammation; unsukumbili (two-days), a name for a herb used for the quick healing of sores and wounds; and umabelejongosi (maidens' breasts), for the yellow orchid whose attractive yellow flowers are used as a love charm.

How do we make sense of this absence of black people their everyday relationships with plants, and conventions of naming from a field of activity called indigenous gardening? What is indigenous about indigenous gardening?

\section{Reconciling and identifying}

There is a small but growing body of scholarly work on indigenous gardening (Murray 2006, Ballard and Jones 2011, Wylie 2014). In most accounts of the history of indigenous gardening in Durban, the recent wave of interest in indigenous gardens by white Durbanites is attributed to the 1960s work of the Brazilian landscape architect, Roberto Burle Marx. Murray (2006: 48) notes that when Marx visited Durban in the 1960s, he demonstrated the beauty and excellence of indigenous plants in his country, inspiring both casual gardeners and city horticulturalists. Ironically, however, in their attempt to escape the drab and provincial suburban gardening of the period, these enthusiasts, instead of using South African indigenous plants, started a craze of Brazilian tropical exotic gardening with a view towards cultivating 'cosmopolitan beauty amidst the "wild" (Murray 2006: 49). If indigenous flora were deemed unsuitable for beautifying the lawns, homes and gated communities of South African settlers, the defeat of white minority rule occasioned a shift in gardening aesthetics and tastes. Developers, nursery owners, horticulturalists, and a whole host of actors are now enamoured by the benefits of indigenous plants as we discuss further below.

Murray (2006: 47) locates indigenous gardening as 'part of erratically emergent 'postcolonial' cultures of settler belonging' through which settlers transplanted themselves (put down roots) amidst what they considered to be harsh, threatening, and barren surroundings. Against this history of rooting the self through differentiation with the native, Murray (2006: 59) suggests that the contemporary turn to the 'indigenous' be read as a sign of the settler's 'burgeoning reconciliation with place and national identification with the land.' If this is indeed the case, then let us examine what this increasing process of reconciliation and identification entails.

First, Murray's history separates the conjoined histories of gardening and botany. A quick glance at the history of Botany in South Africa reveals that appreciation for indigenous plants among whites in the Durban area does not begin in the 1990s, but goes as far 
back as the early colonial period, specifically to the work of various botanists who used to be known as 'classic plant hunters' (McCracken 2011). Some of these hunters included Charles Johnston, Robert Plant, and J. Medley Wood, whose early work in the Durban Botanic Gardens was part of a large global imperial network of botanical plants geared towards both classification and collection, as well as the procurement of economic bounty (Headrick 1996; Schiebinger 2004).

Recounting the journeys of discovery of Robert Plant in the 19th century, McCracken (2011) says his collection of indigenous plants was only possible because of the assistance of natives. Plant often sent his African 'helpers' deep into tsetse-fly country to carry back floral jewels from the botanical treasure house of Maputaland. On one occasion he wrote to a famous trader in rare orchids in England of one of his men who had never returned after being sent to St. Lucia Bay - 'probably died of coast fever. He was one of my best hands and I regret his absence very much' (McCracken 2011: 4).

Tellingly, we know nothing of these black men. 'He was one of my best hands', says Plant; however, 'he' is not named. 'He' and the rest of the 'helpers' were simply drawers of water and hewers of wood. Nameless men who died on unmarked graves. According to this colonial history, the history of indigenous plants, the knowledge that anchored the scientific research around them, is the history of white men. Although the collection of plants was carried out by natives at great cost to their lives, plant hunters took the credit. Men such as Mark McKen, William Gerrard, and John Medley Wood traded these plants in London's markets of natural history products, gaining money, fame, and credentials in the process.

Given this reduction of the social worlds of the colonised to 'hands' and 'help', what besides science is mobilised to define plants as indigenous? Here is the answer provided by the Kloof Conservancy, a non-profit organisation working in Kloof, a town $30 \mathrm{~km}$ west of Durban, which has been vocal in encouraging its members to plant species native to Kloof. Wishing to educate its members on what is indigenous, the Conservancy offers this strict interpretation:

Without overcomplicating the issue, indigenous means being indigenous to Kloof. This would include many plants (the majority) that occur in Kloof and may also occur elsewhere in KwaZulu-Natal or even further in Southern Africa and it also includes the relatively few, rare and truly endemic plants that are only found in Kloof such as the Streptocarpus molweniensis. Often gardeners take a very broad view on what is indigenous but a Fever Tree is just as exotic to Kloof as an English rose bush (Kloof Conservancy).

If the desire to avoid 'overcomplication' alerts one to debate about what is 'indigenous', the Conservancy nevertheless attempts to provide an authoritative criterion that will unilaterally differentiate the indigenous from the non-indigenous. Let us look more closely at the simplification offered. What is immediately striking is the spatial grounding and fixing of the indigenous in the small area of Kloof. Yet, in the very next line, it becomes appar- 
ent that there are very few plants that are found only in Kloof. For as the Conservancy is forced to admit, the majority of the plants that are found in Kloof can be found elsewhere in KwaZulu-Natal and even beyond. If the majority of the plants that are found in Kloof are also found in the rest of the province, why then insist on trying to preserve this sense of spatial exclusivity?

Perhaps the answer lies in the final attempt to conserve the narrowness of the Conservancy's interpretation. The Conservancy attempts to do this by producing an equivalence between 'an English rose bush' and 'umhlosinga' as 'exotic'. While we can understand that an English rosebush might be foreign, we are puzzled by the exoticisation of umhlosinga (or Fever Tree to the Conservancy), a tree recognised as indigenous by the South African National Biodiversity Institute. Furthermore, the tree has long been considered a free source of succour for people in the northern parts of KwaZulu-Natal, who use its bark to treat sore throats and fevers and its hardy wood to fence agricultural fields from hippos. In rendering the everyday practices of black Africans as 'exotic', we wonder if the insistence on trying to fix a narrow and absurd definition of the indigenous might be an attempt to hold on to some form of authority by those unsettled by post-apartheid times.

\section{The conservation ethic}

Indigenous gardening is driven primarily by ecological considerations. The importance of ecological concerns was starkly underlined when the province experienced its worst drought in a century in 2015. Alarming water shortages required concerted government campaigns and funding for water conservation. Thus it was no accident that the 2015 annual indigenous plant fair was co-hosted with the eThekwini Municipality (in which Durban, the largest city in the province, is located) under the theme of 'sustainable living'.

Partly because of this conservation ethic, indigenous gardening is an assemblage ( $\mathrm{Li}$ 2007; Bracking et al. 2012) comprising numerous conservation actors: people (gardeners, workers), agencies, institutions, and organisations such as the South African National Biodiversity Institute, the KZN Botanical Society, the Wildlife and Environment Society of South Africa. Like many similar assemblages, sometimes the goals are not in concert (conservation, profit, aesthetics) and the actors are often in conflict (government, business, and NGOs). However, the ecological imperative is often accompanied by the promise of being close to nature. As one of the organisers of an indigenous garden day says:

Visitors to gardens like these couldn't fail to have been inspired when they saw intact and thriving wild areas and the abundance of life within them. Hopefully, it would have given them food for thought: why get into the car and drive expensively for miles and hours to get into the bush, when by allowing nature to get a foothold and to evolve dynamically in your own garden, you can have your own private nature reserve right on your doorstep? (Abbott 2014). 
Forgotten in this desire to bring nature to one's doorstep is the racialised histories of dispossession underlying the creation of national parks and reserves. Contrary to iconic images of visitors leaning out of their vehicles to photograph nature, national parks were created through the eviction of Africans and the erasure of their presence within nature from the historical record. Occupants of the land were driven out of the prescribed park area, and farmers and hunters were suddenly deemed 'squatters' and 'poachers.' Some, however, were allowed to remain in order to perform necessary labour - often under conditions of indentured servitude (Meskell 2012: 75-79). The native as 'threat to nature' is not a figure of the past alone. As the popularity of indigenous gardening has blossomed, so have heightened concerns about the rapid destruction of indigenous plants by African populations, thanks to the popularity of indigenous medicines and also the expansion of informal settlements in urban areas. Millions of Zulu people use indigenous plants for medicinal purposes. Isiphephetho and a few other medicinal plants are said to be near extinct in the province because of their popularity in muthi (traditional medicine) markets in Durban. A botanist, writing about the World's View Conservancy (WVC) in the Midlands, laments their fate:

[They are threatened by] poaching, be it the hunting of animals by subsistence-oriented hunters or the collection of plants by people wishing to supply to muthi trade... Given that the WVC is located in an increasingly urban area the existence of a large number of potential muthi collectors and consumers nearby, mean that this threat must be taken seriously and policing efforts maintained (de Jager 2014).

This anxiety-ridden sentiment is quite revealing of the politics of conservation. Conserving indigenous plants entails protecting them from being used for medicinal purposes or livelihood. In other words, what we are being asked to do is to preserve certain plants even if it means denying others who are forced to rely on them for their subsistence. We are asked to support the creation of a 'natural' area for the enjoyment of the few through the exclusion of the many who regard nature not so much as an object of contemplation and aesthetics but a provider of material sustenance.

Sustainable living is not only about the preservation of indigenous plants for enjoyment. It is also closely intertwined with the idea of screening. Examining written materials and websites of indigenous gardening industry, we are struck by prevalence of the idea of walls, hedges, screens, etc. For example, writing in the 2015 Indigenous Gardening Handbook, Alex March (2015: 48) of Nkosi Nursery says the following about planting indigenous trees as barriers:

Screening with plants is often required for privacy, and this can double up as a barrier against unwanted intruders while providing a thick and inviting nesting area for many of our suburban bird species. This is probably the cheapest way to screen off your neighbor, 
but you will have to exercise some patience while the plants grow into their new position.

In this quotation, March is alluding to national concerns about safety and security. It is generally agreed that South Africa is one of the most violent countries in the world with extreme high levels of violent crime. Even though blacks are the largest victims of crime (due to their demographic majority) crime is racialised and coded as black. Dominant crime discourses pit supposedly black perpetrators against white victims (Kynocha 2013). Unlike Alex March, the aforementioned Kloof Conservancy is more direct. After its discussion of what indigeneity entails, it goes on to extol the virtues of utilising indigenous plants:

Security is very often an emotional issue and environmental considerations are often 'thrown out of the window' when people's safety is at stake. However some careful planning and wise use of indigenous plants can provide not only excellent security, comparable to most commercial 'security barriers' but also an environmentally acceptable and visually pleasing solution... The creation of 'green corridors' to permit wildlife to move from one area to another is a critical element in the long term survival of our indigenous fauna particularly the small mammals that have adapted to urban living.

This use of indigenous plants for 'screening unwanted intruders' is as old as colonial rule itself. In the 1650s during early Dutch settlement in the Cape, there were often skirmishes with the indigenous Khoi. The Dutch East India Company settlement was placed in the grazing routes of the Khoi. Upon realising that building a wooden fence to keep the indigenous people off the land was too expensive, Jan Van Riebeeck, the first Dutch Commander of the Cape from 1652 to 1662, turned to indigenous plants. Using a hedge of wild almond trees and thorny brambles, he built a border wall that prevented the Khoi from driving through their livestock. This boundary was the first colonial border in South Africa (City of Cape Town n.d.). Part of this hedge is still visible today.

Sustainable living is about conserving indigenous plants and wildlife, and creating corridors to enable the movement of the small mammals that have adapted to urban life. It is also about conserving the authority to name and preserve what is indigenous to a given area. Sustainable living does not involve asking questions about why or how it is that the conservation imperative keeps running up against the subsistence or sustenance efforts of erstwhile natives and their progeny. It does not involve asking questions about why some people have to be continually screened out from nature and culture. Nor does it raise any questions about why such a large number of black people in South Africa lack any meaningful land to garden and reproduce themselves. In the next section, we examine this underside of indigenous gardening, namely, the world of subsistence gardening. 


\section{Displanting the native: the worlds of sub-subsistence agriculture}

Subsistence is a condition, not a choice. If one is a subsistence gardener, one is black, most likely a woman, and very likely lives in one of the former Bantustans (Rangan and Gilmartin 2002: 638; Pienaar and Von Fintel 2014). Given that there is no private ownership of land in these areas, the subsistence gardener does not own land. She farms on small plots of land allocated to her by customary authority, which may or may not be arable (Lahiff 2000: 24). According to Statistics South Africa (2013), over two-thirds of agricultural households in KwaZulu-Natal subsist on matchbox-sized land in their backyards, eking out a miniscule amount of agricultural produce for domestic consumption. A lack of capital and technological inputs, as well as difficulties accessing water and markets, make subsistence a perilous affair (Cousins 2013; Aliber and Hall 2012). Consequently, the food grown though such a lack of means is actually insufficient for ensuring the subsistence of the gardener and her family. At best, the proceeds of subsistence gardening supplement store-bought food and/or other sources of income. In short, subsistence gardening remains an oxymoron, continuing to provide for only a 'sub-subsistence' existence (Bundy 1979).

This condition of sub-subsistence is primarily the result of the success of colonial and apartheid policies. The establishment of native reserves and their subsequent transformation into Bantustans were important to the consolidation and maintenance of White supremacy, for they created a source of cheap labour for the White economy and thwarted the possibility of a unified African nationalism from emerging (Brookes and Hurwitz 1957; Mbeki 1964). With the implementation of the 1913 and 1936 Land Acts, native reserve areas that had been once self-reliant (see Bundy 1979) were transformed into rural slums dependent upon imported food and wage remittances of migrant labour. ${ }^{4}$ The advent of apartheid rule and the transformation of reserves into semi-autonomous 'homelands' shifted the responsibility of rehabilitating these areas onto 'traditional chiefs' created and legitimised by the apartheid authorities (Hendriks and Ntsebeza 1999). The betterment schemes instituted by these chiefs, which involved the culling of livestock and limiting grazing and agricultural land as well as the ownership of livestock, ended up exacerbating inequalities within the Bantustans and creating a 'class' of landless peasants who would be forced to move to settlements close to White areas. Overall the actions of the state and the 'Bantu' authorities created a small prosperous farmer class who benefitted from the concentration of land and subsidisation of cash crop production on the one hand, and a large reservoir of marginalised peasants on the other (Lahiff 2000).

\section{Seeding generativity and invention: imifino encounters}

Given the difficulty of subsistence farming, many small-scale farmers in the former homelands have either given up trying to be self-reliant or embraced commercial farming. Gogo Qho, however, refuses to be governed by such a history and aspires to produce for most of her subsistence needs. Instead of being reliant on store-bought food, she is able 
to largely feed herself on what she grows on two garden plots. It is not so much the size of these plots that enables her to be self-reliant, but the incredible variety of plants, herbs, and fruit trees that she grows in them; at one point we counted 80 different varieties of herbs, vegetables, and fruit trees in her garden. Also crucial to her ability to sustain herself is her reliance on dozens of crops that in most peoples' eyes are 'wild' herbs, plants, vegetables, and trees such as umsuzwane, uxhaphosi, unsukumbili, and of course imbuya. Her crop diversity and vast knowledge of indigenous plants, together with her agro-ecological methods make her stand out among other farmers we have spoken with in the Mtubatuba area. As we have documented elsewhere (2016), Gogo Qho faces tremendous challenges in her attempt to cultivate her autonomy. Her social role as a grandmother demands that she participate in a gendered economy of household care that sometimes conflicts with her work. In Mtuba (like in other parts of rural South Africa), access to land is curtailed not only by the history of racialised dispossession, but also by contemporary 'customary' practices that often disadvantage women (O'Laughlin 2009). Furthermore, thanks to centuries of colonisation of the diet, her indigenous produce and products are not very popular in the local markets. Despite these challenges, her commitment to her work and her desire for autonomy is unflinching. When asked about why is she so adamant in pursuing food autonomy, here is how Gogo Qho responds:

Commercial farmers and those whose desire is profit don't care about the nutritional content of their vegetables, only money. I need to know the healing properties or elements of these crops. For example, I know that some sweet potatoes, the monate variety for example, are excellent for people with low CD count; dagga is good for your blood pressure; imbuya has lots of iron and is good for your blood during menstruation, etc.

Taking this comment as a clue pointing to enmeshment of lifestyles and life worlds in matters of livelihood, we peek into a realm that refuses to be governed completely by the material conditions and cognitive apparatus of white supremacy.

\section{Of dreams and desires}

Gogo Qho was born about sixty-six years ago (or sixty-one if you go by her official documents) in the village of KwaKwiliza, also in the Mtubatuba area. While we are still learning about her childhood, her accounts indicate a close relationship with her father, which allowed her to imbibe his indigenous knowledge of plants and medicine. Thanks to the dispossession discussed above, she, like many of her peers, was forced to 'migrate' to the city as a young adult to sell her labour-power. She worked in Durban, Richards Bay, and Mtubatuba town, taking up a number of jobs in succession, including one as a domestic aide to a white family. The photographs she shares with us provide a glimpse into her life during this time: In one shot, she stands in front of the school where she worked, wearing a fashionable dress; in another, she sips a soda, with a pair of sunglasses sitting atop her 
forehead. Today, she refers to the aspirations intimated in these photos as belonging to another time, one dominated by what she calls the way of the city, a way antithetical to a life of the soil.

This transition was occasioned by an unlikely source; a severe car accident that left her in a great deal of pain and unable to walk. A lengthy convalescence followed, one made unbearable by the failure of biomedicine to cure her. Her accounts suggest that she saw this time of physiological unsettlement as a deep-rooted malady that called her for to get back in tune with both nature and her ancestors. It made her rethink her life, which until then had been dominated by the pursuit of a formal job and the trappings of 'city' life. This is how she recounts the inspirational fount of her work:

I had been ill for a while after I was involved in a car accident, more than a decade ago. I was shuffled from doctor to doctor but they could do nothing. While they were watching me, I was watching them! They were giving the same medicines and pills to everyone regardless of their affliction. One night, my grandmother appears to me and shows me that it was the food I was eating that militated against my health. I had to go back to the soil and eat from nature.

In this account of the failure of biomedicine, we see both an awareness of the objectification of biomedicine as well as a refusal to be governed by it (see Nandy and Visvanathan 1995). In saying that biomedicine dispenses the same palliatives to everyone, she offers a diagnosis of the inadequacy of medicine. Medicine, by virtue of its objectivity, is blind to the situational nature of the patient's illness. Hence it can only concern itself with the somatic domain (Fanon 1967: 10). This awareness allows her to turn the tables on biomedicine. She refuses to be objectified by the protocols of biomedicine, and instead asserts subjectivity. She was no longer a patient, an object under the microscopic gaze of medicine: 'I was watching them!' she declares.

If Gogo Qho's claim to subjectivity is not, and cannot be, recognised by biomedicine, it nevertheless is heard. For soon after, her grandmother instructed her: 'You need to eat from the soil!' What makes this encounter remarkable for us is that her grandmother has long been deceased - something we learn because we ask. In her narration of this encounter, this is not a voice from the past, nor is it epistemologically qualified as a dream: 'One night my grandmother appears to me...' The epistemological distinction between the historical and the non-historical does not exist for her.

Gogo Qho does not interpret her grandmother's instruction to 'go back to the soil', as an injunction to go back to a particular place. She does not take her grandmother to be saying she needed to go back to her ancestral place. Instead, she hears in it a suggestion to begin a way of life that is attached to the soil. Soil, here, connotes a way of life, rather than a sense of belonging that is tied to territory or particular homelands. Following this suggestion, she sets on a path of cultivation, which over time allows her to recover from the accident. Thus, she leaves the 'city', settles in the village of KwaBhoboza, and begins cultivating herbs, climbers, and vegetables utilising ancestral knowledge. 
As she narrates her embrace of cultivation, an account produced and reiterated by our prodding, Gogo Qho affords us a glimpse into the life-worlds of the dispossessed. Here the past is neither dead nor fully separate from the present, but rather co-exists with it. The past is not an objectified archive waiting to be exhibited or plumbed by the professional knowledge dispenser or the bureaucrat, but rather one that is in dialogue with the self. This ability to travel between what are held apart by political ideologies (settler and native, modern and tradition, past and present) is but one way of introducing invention into what otherwise would be a sub-subsistence existence (Fanon 2008: 201). Invention here does not consist of a search for an authentic past, but involves transgressions between the modern and the traditional, scientific and indigenous, native and non-native. Below, we briefly explore these transgressions and the kinds of openings that are revealed through them.

\section{Fluid knowledges}

Because her cultivation is driven by the imperatives of healing and nutrition, Gogo Qho spends an inordinate amount of time identifying each plant and its medicinal and culinary properties to us. While it is tempting to think of indigenous knowledge as a 'storehouse' passed from generation to generation, it is better thought of as a dynamic process that is not always impelled by humanly discernible aims or constrained by epistemic distinctions between different kinds of knowledges.

On a particularly difficult afternoon, we had spent hours walking up and down the slope of her garden watering plants with 10-litre buckets. It was the middle of winter and the water pipes were dry, so this involved numerous 100-yard trips to the stream trickling at the foot of the garden. We were beyond exhausted when she asked us to water some unrecognisable plant. 'What is this, Gogo?' we asked. 'I don't know', she said. 'What do you mean you don't know?'

I rescued that nkunzana at the construction site near the garage. They are building a major water pipe there and I've heard they will put a bridge at the intersection. The big tractors and graders had uprooted the land and I saw this fellow just lying there asking for mercy. I rescued him.

We are familiar with the ongoing construction near the highway. But her referral to this plant as one would to a little mischievous boy leaves us momentarily speechless. Many weeks previously, she had felt pity for a nameless, unidentifiable plant and here she was asking us to also nurture it. Unlike ecologists and botanists, architects and conservationists, she feels no compunction to 'define and rule' (Mamdani 2012), to name and classify, or even to know. It didn't matter whether the plant was indigenous or not. Driven by the need to explain, we pressed her for motive. That morning, we had seen hundreds of neat little white crosses erected on the side of the road between Mtuba and the tourist town of St. Lucia. Each one was in memory of a rhino killed that year. However, there were no arguments in favour of biodiversity or ecological conservation forthcoming from Gogo. 
She seemed genuinely puzzled by our repeated questions. Perhaps she was puzzled by our lack of consideration for a vulnerable being sans a legitimising ideology.

Gogo Qho's knowledge of indigenous and non-indigenous plants is nurtured by a number of sources, some expected and others more surprising. The multiple sources and processes through which she continues to gain knowledge speak to the notion of 'cognitive justice' (Visvanathan 2006) which emphasises that the dispossessed have their own notions of inventing and coping that depart from those of the expert and the bureaucrat. While much of Gogo Qho's knowledge of the culinary and medicinal properties of indigenous plants came from her father, her use of agro-ecological practices stems from permaculture training she received at a nearby school. While the training was mainly intended for school teachers, Gogo Qho, upon hearing of it, somehow managed to persuade the trainer to include her in the workshop. The training taught her to use goat droppings, fruit peel, and animal bones for fertiliser, as well as to intercrop different plants to maximise ecological effectiveness. What is significant about this training is that while it is clear from her lectures that Gogo Qho has learned the technical aspects of permaculture, she nevertheless does not justify or explain her actions through discourses of environmentalism or ecological stewardship. She does not ask us to save the environment or the earth. Instead, she urges us to plant imbuya because it requires very little water, grows easily, and is nutritious.

Sometimes when Gogo Qho's curiosity about some plant runs ahead of her knowledge, we have found ourselves assigned with homework. One such task required us to go on the Internet and find information about umdumbula because she had heard it was popular in West Africa. There were no accompanying riders about where to get the information or about what kind of information was acceptable. For the expert this indifference to the epistemic distinction between Wikipedia and the Journal of South African Botany would be deeply troubling. When we reported what we had found, there were no questions about how it was gained, whether it was reliable, or how it had been sanctioned. Instead, our efforts were met with an acknowledgement of thanks. What for the expert would be a cavalier attitude is perhaps an indifference to the boundaries as well as hierarchies separating different kinds of knowledges. This indifference is different from a position that holds that indigenous knowledge and science are equal and equally valid, because it does not seek to justify the validity of indigenous knowledge. In fact, 'indigenous knowledge' does not materialise as a discrete entity.

\section{The commons}

Crucial to the success of Gogo Qho's gardening is the existence of a commons of material and intellectual resources. Before proceeding any further, it is important to note that she, like many of her peers, is not in favour of the cooperative farming schemes being promoted by the postcolonial state in its bid to improve the productivity of the subsistence sector. Such schemes, she says, reward the lazy at the expense of the hardworking. However, this does not mean that she espouses the ruggedly individualist figure touted by neoliberalism. 
Instead, she is bound by a host of relations with other farmers, most of whom are women. The commons that emerges in these encounters is not one of commodities or patented knowledge, but a zone that arises in the wake of curiosity, improvisation, memory and need, which are sometimes (but not always) provoked by the expropriation of nature by the powerful.

During one of our conversations, Gogo Qho requested to be driven to the plant nursery in town: 'there is a rare plant that I think umfaz' womlungu (white woman) sells there.' We got there and indeed it was there. 'It' turned out be a stunted basil tree. She bought two for R25. This would have remained an unremarkable transaction except for what happened the following day. We had driven some 25 minutes to the north to eGunjaneni to collect goat droppings from Ms Magwaza, another farmer. After half an hour of filling containers and bags, Gogo Qho suddenly yelled, 'Mvu, awungibukise nawu umhlolo wemihlolo' (Mvu, do you see this wonder of wonders!). 'Amehlo ami yini?' (Are my lying eyes deceiving me?) Mvu asked. There, outside Ms Magwaza's home were hundreds of the same wild basil plants we had purchased the previous day. Hearing our animated dialogue, Ms Magwaza was surprised. She hadn't known what the plant was or that it was edible. All she knew about it was that it was an annoying wild weed that the goats ate. She was amazed to learn it could garnish food.

If the episode about the wild basil illustrated the threat posed to the commons by science and commerce, another one serves as a different and more fortuitous illustration of the knowledge exchanges that characterise the commons, and the distance between this knowledge and that of the (disciplinary) kind being reproduced here by us. That episode occurred when the three of us visited another farmer, Ms Mfekaye, who lived about a 20-minute drive away from KwaBhoboza. Originally the two of us had arranged to come alone, but were joined by Gogo Qho at the last minute when she heard where we were headed. 'I saw some yarrow around there when I was in the area a few years ago, and I have been waiting to go back there', she said. Our scepticism of this claim was disproven soon after our arrival. For growing there in the middle of a yard was the aforementioned yarrow. After a long conversation that ensued after yarrow cuttings were gathered, the four of us toured Ms Mfekaye's garden. What was most striking was that while we had managed the conversation until then by virtue of asking all the questions, the moment we got to the garden, the two farmers animatedly starting talking together about each and every plant that they came across. Before too long, Ms Mfekaye went in, came out with a notebook and asked Mvu to start taking notes of their conversation which revolved around how to grow different plants and weeds and their medicinal and culinary uses. At one point, Gogo Qho explained with delight when she came across some fennel, as it appeared to be of a variety that she had not come across before. As we parted with a variety of cuttings in hand, she gave instructions on how to mix lemongrass, sage, and parsley to prepare a remedy for a sinus problem that Ms Mfekaye's daughter was undergoing. Standing at the periphery and very conscious of our own illiteracy, we could only reflect on the knowledge, innovativeness, and conviviality of the commons at that moment. 


\section{Conclusion}

The category 'indigenous' has been creatively deployed by many African activists to win international and continental recognition. As a normative and legal category, indigeneity is primarily affiliated with transnational rights-based social movements that support the struggles of indigenous peoples against the depredations of past and present colonial orders. As such, their demands are made against the state or multilateral institutions. Although indigeneity in this sense has yielded indisputable benefits for some of the world's indigenous peoples, we have explored the complications of this category from the vantage point of post-apartheid South Africa where the transmission and overlay of this concept is fraught with friction and awkward encounters. Unlike in other parts of the world (especially in Australia, New Zealand, and North America) where indigenous peoples are a minority and present their claims against settler descendants, it is quite complex and awkward in South Africa, where such claims are addressed to a postcolonial state of fellow sufferers. A linear understanding of indigeneity does not contend with the crooked lines of subordination and liberation.

Indigeneity as a conscious category also fails at other levels. Because of its plasticity, the category indigenous has ironically been marshalled by white South Africans. Although they do not claim indigeneity, they use indigenous flora as a proxy to forge belonging. As we show, this attempt also produces frictions and absurd categories as it tries to resurrect colonial/apartheid temporality during an uncertain present. The attempt to fix indigeneity through scientific classification valorises ornamental indigenous flora but expunges the historical record of the erasure of indigenous populations from the lands that are gardened. In other words, productions of colonial temporality do not end with the defeat of apartheid but continue to govern the meaning of 'indigenous' put forth in practices of indigenous gardening.

If the Khoisan indigenous walk is an attempt to answer colonialism on its own terms by following its logic of prior-ity, Gogo Qho, on the other hand, has a non-teleological creative understanding of history. She cultivates a circular relationship with time and her plants. Although her work is structured and limited by the historical injury of colonial and apartheid rule, there is a self-actualisation in her work that reveals an imaginary that goes beyond the historical parameters of apartheid and colonial rule. Unlike the pervasive resurrection of the colonial past that we see in indigenous gardening, the social relations of Gogo Qho allow her to escape the confines of colonial categories by keeping alive dynamic and open-ended notions of indigeneity, knowledge, and selfhood. Ungoverned by distinctions between the historical and the non-historical, science and indigeneity, private property and the commons, these social relations materialise a world where gardening nourishes not only the body, but also one's ancestors, neighbours, and a world of knowledge beyond the grasp of the colonial botanist, the indigenous gardener, the ecologist, the metropolitan homeowner, and even us. 


\section{Notes}

1 Building upon existing segregationist policies, this Act concretised the division of urban areas into racially segregated zones. It criminalised residence on and ownership of land in an area designated for another racial group.

2 This Act further controlled the mobility of black Africans by requiring that they carry passbooks with them wherever they went. Moreover, Africans, both men and women, were required to obtain permits before being able to leave rural areas or seek employment in urban areas.

3 'Out of the blackest mud, come the whitest lilies' - so begins an article in The Gardener describing this plant. See http://www.thegardener.co.za/kb/article.php?id=515; accessed 8 January 2016.

4 See Lahiff (2007). The native reserves comprising 13 per cent of the land would end up accommodating 40 per cent of the population. At the end of apartheid, Whites making up 11 per cent of the population controlled 86 per cent of agricultural land.

\section{References}

Abbott, Andrea. 2014. 'The Relevance of the Kloof Indigenous Garden Day to Biodiversity Protection in the Upper Highway'. The Leopard's Echo, July issue.

Alfred, Taiaiake and Jeff Corntassel. 2005. 'Being Indigenous: Resurgences against Contemporary Colonialism' Government and Opposition: An International Journal of Comparative Politics 40(4): 597-614.

Aliber, Michael and Ruth Hall. 2012. 'Support for Smallholder Farmers in South Africa: Challenges of Scale and Strategy'. Development Southern Africa 29 (4): 548-62.

Anaya, James. 2004. Indigenous Peoples in International Law. Oxford: Oxford University Press.

Appadurai, Arjun. 1990. 'Disjuncture and Difference in the Global Cultural Economy'. Theory, Culture and Society 7 (2): 295-310.

Ashforth, Adam. 1990. The Politics of Official Discourse in Twentieth-Century South Africa. Oxford: Clarendon Press.

Ballard, Richard and Gareth A Jones. 2011. 'Natural Neighbors: Indigenous Landscapes and "Ecoestates" in Durban, South Africa.' Annals of the Association of American Geographers 101 (1): 131-48.

Barbieri, Chiara, Tom Guldemann, Christfried Naumann, Linda Gerlach, Falko Berthold, Hirosi Nakagawa, Sununguko W Mpoloka, Mark Stoneking and Brigitte Pakendorf. 2014. 'Unraveling the Complex Maternal History of Southern African Khoisan Populations'. American Journal of Physical Anthropology 153: 435-48.

Bracking, Sarah, Dan Brockington, Patrick Bond, Bram Büscher, James Igoe, Sian Sullivan and Philip Woodhouse. 2014. Initial research design: 'Human, non-human and environmental value systems: an impossible frontier?' Leverhulme Centre for the Study of Value (LCSV) Working Paper Series NO. 1. Available at: <http://thestudyofvalue.org/wp- content/uploads/2013/11/WP1-InitialResearch- Design-final.pdf $>$.

Brookes, Edgar and Nathaniel Hurwitz. 1957. The Native Reserves of Natal. Cape Town: Oxford University Press.

Bundy, Colin. 1979. The Rise and Fall of the South African Peasantry. London: Heinemann. 
City of Cape Town (n.d.) [online] 'The Origins and History of The Company's Garden'. Available at: $<$ https://www.capetown.gov.za/en/parks/facilities/Pages/TheoriginshistoryTheCompanyGarden. aspx $>$ [Accessed on 20 December 2015].

Comaroff, John and Jean L Comaroff. 2001. 'Naturing the Nation: Aliens, Apocalypse and the Postcolonial State.' Journal of Southern African Studies 27 (3): 627-51.

Cousins, Ben. 2013. 'Smallholder Irrigation Schemes, Agrarian Reform and "Accumulation from Above and from Below" in South Africa'. Journal of Agrarian Change 13 (1): 116-39.

de Jager, Paul. 2014. 'Observations, Impressions, Comments and Suggestions', The World's View Conservancy, April 2014. Available at: <https://worldsviewconservancy.wordpress.com/tag/conservation/> [Accessed on 15 January 2016].

De la Cadena, Marisol and Orin Starn (eds). 2007. Indigenous Experience Today. Oxford: Berg.

Dubow, Saul. 1989. Racial Segregation and the Origins of Apartheid in South Africa, 1919-36. London: Macmillan Press.

Fanon, Fanon. 1967. Toward the African Revolution: Political Essays (trans. Haakon Chevalier). New York: Grove Press.

2008. Black Skin, White Masks (Trans. Richard Philcox). New York: Grove Press.

Geschiere, Peter and Francis B Nyamnjoh. 2000. 'Capitalism and Autochthony: The Seesaw of Mobility and Belonging. Public Culture 12 (2): 423-52.

Headrick, Daniel. 1996. 'Botany, Chemistry, and Tropical Development'. Journal of World History 7 (1): $1-20$.

Hendriks, Fred and Lungisile Ntsebeza. 1999. 'Chiefs and Rural Local Government in Post-Apartheid South Africa'. African Journal of Political Science 4(1): 99-126.

Hodgson, Dorothy L. 2009. 'Becoming Indigenous in Africa'. African Studies Review 52: 1-32.

Ives, Sarah. 2014. 'Farming the South African "Bush": Ecologies of exclusion and belonging in rooibos tea'. American Ethnologist 41 (4): 698-714.

Kloof Conservancy. 'Indigenous Gardening.' [online] Available at: <http://www.kloofconservancy. org.za/local-info/indigenous-gardening/> [Accessed on 15 April 2016].

Kynocha, Gary. 2013. 'Fear and Alienation: Narratives of Crime and Race in Post-Apartheid South Africa.' Canadian Journal of African Studies 47 (3): 427-41

Lahiff, Edward. 2000. An Apartheid Oasis? Agriculture and Rural Livelihoods in Venda. London: Frank Cass.

2007. “Willing Buyer, Willing Seller”: South Africa’s Failed Experiment in Market-led

Agrarian Reform. Third World Quarterly, 28(8): 1577-97.

Lee, Richard Borshay. 2003. 'Indigenous Rights and the Politics of Identity in Post-Apartheid Southern Africa'. In Bartholomew Dean and Jerome M Levi (eds). At the risk of being heard: identity, indigenous rights, and postcolonial states. Michigan: Michigan University Press, pp. 80-111.

2006. 'Twenty-first Century Indigenism'. Anthropological Theory 6(4): 455-79.

Li, Tania Murray. 2000. 'Articulating Indigenous Identity in Indonesia: Resource Politics and the Tribal Slot'. Comparative Studies in Society and History 42(1):149-79.

. 2007. 'Practices of Assemblage and Community Forest Management'. Economy and society 36(2): 263-93. 
Mamdani, Mahmood. 2012. Define and Rule: Native as Political Identity. Cambridge, MA: Harvard University Press.

March, Alex. 2015. 'Barrier and Screening Plants'. In 2015 Indigenous Gardening Handbook, Durban: Botanical Society of South Africa, KZN Coastal Branch.

Mbeki, Govan. 1964. South Africa: The Peasants' Revolt. Harmondsworth: Penguin Books.

McCracken, Donal P. 2011. 'Robert Plant (1818-1858): A Victorian plant hunter in Natal, Zululand, Mauritius and the Seychelles.' South African Journal of Science 107 (3/4) Art. \#359, 7 pages. DOI:10.4102/sajs.v107i3/4.359

Merlan, Francesca. 2009. 'Indigeneity: Global and Local'. Current Anthropology 50 (3): 303-33.

Meskell, Lynn. 2012. The Nature of Heritage: The New South Africa. Oxford: John Wiley \& Sons.

Moreton-Robinson, Aileen (ed). 2007. Sovereign Subjects: Indigenous Sovereignty Matters, Crows Nest: Allen and Unwin.

Murray, Sally-Ann. 2006. 'The Idea of Gardening: Plants, Bewilderment and Indigenous Identity in South Africa'. English in Africa 33(2): 24-46.

Nandy, Ashis and Shiv Visvanathan. 1995. 'Modern Medicine and its Non-Modern Critics'. In Ashis Nandy. The Savage Freud and Other Essays on Possible and Retrievable Selves. Princeton: Princeton University Press, pp. 145-195.

Neocosmos, Michael. 2006. From 'Foreign Natives' to 'Native Foreigners': Explaining Xenophobia in Post-Apartheid South Africa. [online] Dakar: CODESRIA. Available at: <http://www.codesria.org/ spip.php?article1415> [Accessed on 15 December 2015].

Nestlé 2015. 'Minister Pandor Lauds Successful Results of Research Partnership'. Nestlé South Africa: Press Statement [online]. Available at: <http://www.nestle.co.za/media/pressreleases/ministerpandor-lauds-successful-results-of-research-partnership > [Accessed on 31 December 2015].

News24. 2016. 'San Descendants in Trek for Heritage,' 18 February 2016. Available at: <http://www. news24.com/SouthAfrica/News/san-descendants-in-trek-for-heritage-20160218> [Accessed on 12 April 2016].

Ngcoya, Mvuselelo and Narendran Kumarakulasingam. 2016. 'The Lived Experience of Food Sovereignty: Gender, Indigenous Crops and Small-Scale Farming in Mtubatuba, South Africa. Journal of Agrarian Change, doi: 10.1111/joac.12170.

Nietschmann, Bernard. 1994. 'The Fourth World: Nations Versus States'. In George J Demko and William B Wood (eds), Reordering the World: Geopolitical Perspectives on the 21st Century. Philadelphia: Westview Press, pp. 225-42.

Niezen, Ronald. 2003. The Origins of Indigenism: Human Rights and the Politics of Identity. Los Angeles: University of California Press.

Ntuli, Nontuthuko R, Alpheus M Zobolo, Stefan J Siebert and Rufalo M Madakadze. 2012. 'Traditional Leafy Vegetables of Northern KwaZulu-Natal, South Africa: Has Indigenous Knowledge Expanded the Menu?' African Journal of Agricultural Research 7 (45):6027-34.

O’Laughlin, Bridget. 2009. 'Gender Justice, Land and the Agrarian Question in Southern Africa'. In A. Haroon Akram-Lodhi and Cristóbal Kay (eds), Peasants and Globalization Political Economy, Rural Transformation and the Agrarian Question. London: Routledge.

Pienaar, Louw and Dieter Von Fintel. 2014. 'Hunger in the Former Apartheid Homelands: Determinants of Convergence One Century after the 1913 Land Act'. Agrekon 53 (4): 38-67. 
Pratt, Mary Louise. 2007. 'Afterword: Indigeneity today'. In Marisol de la Cadena and Orin Starn (eds), Indigenous Experience Today. Oxford: Berg. pp. 397-404.

Rangan, Haripriya and Mary Gilmartin. 2002. 'Gender, Traditional Authority, and the Politics of Rural Reform in South Africa'. Development and Change 33 (4): 633-58.

Riebesel, Katharina. 2015. 'Khoisan in “liberation” walk to deliver petition fighting for customs', The Cape Times, 03 March 2015. Available at: <http://www.iol.co.za/capetimes/khoisan-in-liberationwalk-to-deliver-petition-fighting-for-customs-1826163> [Accessed on 12 April 2016].

Schiebinger, Londa. 2004. Plants and Empire, Colonial Bioprospecting in the Atlantic World. Cambridge: Harvard University Press.

Schweitzer, Erwin. 2015. The Making of Griqua, Inc.: Indigenous struggles for land and autonomy in South Africa. Berlin: LIT Verlag.

Statistics South Africa, 2013. Census 2011: Agricultural Households. Report no. 03-11-01 (2011), Pretoria: Statistics South Africa. Available at: <http://www.statssa.gov.za/census/census_2011/census_products/Agricultural_Households.pdf> [Accessed on 1 September 2015].

Tsing, Anna. 2005. Friction: An Ethnography of Global Connection. Princeton: Princeton University Press.

Visvanathan, Shiv. 2006. 'Alternative Science'. Theory, Culture \& Society 23 (2-3): 164-9.

Vorster, Ineke H J, Jansen van Rensburg Willem, Van Zijl J J B and L Venter Sonja. 2007. 'Re-Creating Awareness of Traditional Leafy Vegetables in Communities'. African Journal of Food Agriculture: Nutrition and Development 7(4): 1-10.

Wylie, Dan. 2014. “The Garden of Love's Decay”: The Suburban Garden as Eco-poetic Space in South Africa'. Scrutiny 2, 19(2): 6-17, DOI: 10.1080/18125441.2014.948039.

\section{Acknowledgements}

We wish to thank Reina Neufeldt, Quỳnh N Phạm, Aparna Devare as well as the anonymous reviewers and editorship of Contexto Internacional for their feedback and suggestions. This work is based upon research supported by South Africa's National Research Foundation and Department of Science and Technology under the Indigenous Knowledge Systems (IKS) programme.

\section{About the authors}

Narendran Kumarakulasingam is an honorary research fellow at the School of Built Environment and Development Studies, University of KwaZulu-Natal, Durban, and a visiting scholar with the Centre for Refugee Studies, York University, Toronto. He is currently working on a manuscript exploring how distinctions between savage and civilised violence are drawn in international politics. Most recently, he has published in the Journal of Narrative Politics and Journal of Agrarian Change (co-authored with Mvuselelo Ngcoya), and has a forthcoming chapter in Quỳnh N. Phạm and Robbie Shilliam (eds) Meanings of Bandung: Postcolonial Orders and Decolonial Visions (Rowman \& Littlefield Press, 2017). His research interests include critical international relations, postcolonial theory, indigenous food and South Asian politics. 
Mvuselelo Ngcoya teaches agrarian studies in the School of Built Environment and Development Studies at the University of KwaZulu-Natal. His main area of research revolves around food production, particularly the social life and political economy of indigenous plants. His collaboration with Narendran Kumarakulasingam on this topic has yielded a paper in the Journal of Agrarian Change (2016) and a book chapter in Knowledge Production in and about Africa (edited by Hana Horáková, LIT Verlag 2016). He also does work on decolonial conceptions of the international in International Relations. His recent paper on this topic, Ubuntu Cosmopolitanism, was published in International Political Sociology in 2015.

Received on 18 January 2016 and approved for publication on 20 July 2016. 